\title{
FEDERAL CONTROL OF RAILROADS IN WAR TIME
}

\section{By Max Thelen}

On December 26, 1917, President Wilson issued his historic proclamation taking possession and control of the railroads of the United States and appointing William G. McAdoo, Secretary of the Treasury, as Director General of Railroads. By this bold and timely act, the President, in a single moment, accomplished an economic change of tremendous significance and of far-reaching potentiality for increased national efficiency during the war.

The American railroad system of which the government of the United States is now officially in possession and control, is a system of 262,000 miles, constituting over 40 per cent of the railroad mileage of the entire world, a system with securities outstanding in excess of $\$ 17,000,000,000$, a system to which the American people have always pointed with pride as the best of all railroad systems.

In addressing myself to my subject, Federal Control of Railroads in War Time, I shall first describe the organization of our railroads during the war prior to the President's proclamation. Next I shall consider some of the problems with which the railroads have been confronted during the war. Then I shall draw attention to the solutions of the problem suggested by the Interstate Commerce Commission and to the solution made effective by the President's proclamation. Finally, I shall give some consideration to the results which may reasonably be expected to follow from government operation of the railroads during the war.

\section{War Organization of Railroads in Other Countries}

In all the principal nations of Europe, the railroads are being operated during this war by the government.

In England, prior to the present war, private capital had always owned and operated the railroads. On August 4, 1914, the very day on which England declared war against Germany, the British government took over the operation of all the railroads. A committee of which a Cabinet member is the general chairman manages the railroads but their actual operation remains in the hands of 
the former operators. All government traffic is carried free and no account thereof is kept. The government guarantees to the holders of railroad securities the same net revenue as the railroads earned in 1913, the last complete year before the war. If there is a surplus, the government keeps it and if there is a deficit the government meets it out of the treasury.

In France, prior to the war, one railroad was owned and operated by the government and the others were owned and operated by private capital. Upon the outbreak of the war the French government immediately took over the operation of all the railroads.

In Germany and Italy, the railroads were owned and operated by the government prior to the outbreak of the war. In these countries public ownership and operation have continued during the war.

\section{War Organization of Railroads in the United States,} April 6-December 28, 1917

In the United States, with the exception of the Panama Canal Zone and approximately 250 miles of railroad in Alaska, our railroads have been owned and operated by private capital. Prior to December 28, 1917, the United States was the only nation of any consequence which during this war continued the ownership and operation of its railroads by private capital.

On August 29, 1916, more than seven months prior to the entry of the United States into the world contest, this government cleared the way for the operation of our railroads directly by the government, if such course should become necessary in war time. On that day President Wilson signed the Army Bill, which bill provided in part as follows:

The President, in time of war, is empowered, through the Secretary of War, to take possession and assume control of any system or systems of transportation, or any part thereof, and to utilize the same to the exclusion, as far as may be necessary, of all other traffic thereon for the transfer or transportation of troops, war material and equipment, or for such other purposes connected with the emergency as may be needful or desirable.

This is the provision of law on which President Wilson particularly relied in issuing his proclamation of December 26, 1917. Prior to this proclamation, the power conferred by this sentence of the Army Bill of 1916 had been exercised by the government with reference to only one small railroad in New Jersey. 
On April 6, 1917, the Congress of the United States declared that a state of war existed between the United States and Germany. On the preceding day, Franklin K. Lane, Secretary of the Interior, introduced and had passed by the Council of National Defense the following resolution:

Resolved, That Commissioner Willard be requested to call upon the railroads to organize their business so as to lead to the greatest expedition in the movement of freight.

Acting in accordance with this resolution, the principal railroad executives of the country met in Washington on April 11, 1917, and resolved that during the war they would coördinate their operations in a continental railway system, merging during such period all their merely individual and competitive activities in the effort to produce a maximum of national transportation efficiency. The direction of the continental railway system thus organized was placed by the railroads in the hands of the executive committee of the Special Committee on National Defense of the American Railway Association. This executive committee was also known as the Railroads' War Board.

Under this resolution, the railroads of the United States continued until December 28, 1917, to be operated under private ownership and private management.

On May 29, 1917, President Wilson signed an act of Congress giving to the Interstate Commerce Commission jurisdiction over railroad cars used in the transportation of property by any carrier subject to the provisions of the Interstate Commerce Act. The Interstate Commerce Commission thereupon created a Division of Car Service. Authority with reference to car service was also claimed and exercised by a committee of the railroads known as the Committee on Car Service of the American Railway Association, and by the War Department, the Navy Department, the National Food Administration, the National Fuel Administration and the Shipping Board.

While the Interstate Commerce Commission was thus granted all the necessary authority to act, the Commission has thus far issued no order under the car service statute and has been content to permit questions of car service to be disposed of largely by the railroads' own committee on car service. The fact that at least 
six separate and distinct authorities, five governmental and one private, assumed jurisdiction over the question of car service of course resulted in great confusion and inevitably demanded that the entire matter be placed in charge of a single responsible authority.

On August 10, 1917, President Wilson signed an act of Congress making it unlawful by physical force or by threats of physical force to obstruct or retard the movement of cars or trains engaged in interstate or foreign commerce. The same act authorized the President, whenever he may find it necessary for the national defense and security, to direct that such traffic as, in his judgment, may be essential to the national defense and security, shall have preference or priority in transportation. The President is authorized for this purpose to issue orders either directly or through such person or persons as he may designate for that purpose or through the Interstate Commerce Commission.

Under this statute, President Wilson appointed Robert S. Lovett as Director of Priority in Transportation. Judge Lovett issued five orders calling for priority in railroad transportation. The first order provides for preferential shipments of bituminous coal to points on the Great Lakes. The second order declares that open top cars other than flat cars shall not be used for the transportation of materials and supplies for the construction or repair of streets, roads and highways, theatres and other buildings used for amusement or of pleasure vehicles, furniture or musical instruments. The third order provides for the priority of the transportation of coal from the coal mines of Utah and Wyoming to the west and the northwest. The fourth order provides that the railroads of Texas shall give preference to the transportation of cottonseed cake and cottonseed meal to feed the starving cattle in Texas and New Mexico. The fifth order designates the order in which materials and supplies for the government, war industries and other essential industries shall have preference or priority in car supply and movement.

The reason for the enactment of the Priority Statute was the frank statement of the railroads that they would be unable during the war under their existing organizations to carry all the traffic which might be offered for transportation and their desire that some legal method might be provided by which priority or prefer- 
ence in transportation might be given to the most essential commodities.

\section{Special War Problems}

Having sketched the organization effected by the railroads and the official action taken by the government prior to the proclamation of December 26, 1917, I shall now address myself to a few of the more important problems with which our railroads were confronted as the result of the war.

In this connection I shall refer first to the car shortage problem, then to the financial condition of the railroads and then to the difficulty of securing labor and equipment.

\section{Car Shortage}

From the nation's point of view, the most serious problem with which the railroads have been confronted is their growing inability to transport the nation's traffic. Car shortage is not a new phenomenon. It existed in the United States prior to our entry into the war. A serious car shortage existed in the fall of 1912. During the latter part of 1916 and the early part of this year the car shortage situation, as is well known, was acute. The car shortage which existed prior to our entry into the war has been accentuated by it. The congestion of terminal facilities, the requisitioning of coastwise shipping by the federal government, the tremendous increase in the number and output of industries engaged directly or indirectly in the manufacture of materials and supplies used in war, and the transportation of men and materials to and from our army cantonments have all served to increase the difficulties encountered by the railroads in seeking to transport the nation's traffic.

Active coöperation between the railroads, the shippers and the public authorities materially increased car efficiency. The shippers exercised greater promptness in the loading and unloading of cars and greatly assisted by loading cars to capacity. The railroads increased the daily mileage of freight cars and locomotives, decreased the time during which equipment was in repair shops, eliminated some unnecessary passenger mileage and requisitioned between 150,000 and 200,000 empty freight cars from railroad systems where they were not immediately needed to other parts of the country where most needed. The public authorities, both state 
and federal, gave publicity to the existing conditions and advised and encouraged both the railroads and the shippers to do their full part to help meet the exigency.

The net result of the combined activities of the railroads, the shippers and the public authorities was stated by the Railroads' War Board to be an increase in the efficiency of the existing equipment amounting to approximately 15 per cent. In other words, after the entry of the United States into the war, practically the same amount of railroad equipment handled approximately 15 per cent more traffic than was handled before the war.

For a while, the reports on unfilled car requirements, as published by the railroads, showed apparently a great improvement in the situation. The car shortage, as shown by these reports, decreased from 148,627 cars on May 1 to 31,591 cars on September 1 . However, by October 1 the car shortage increased to 70,380 cars and by November 1 to approximately 140,000 cars and subsequent to November 1 the situation continued to grow worse. Under these conditions, more drastic suggestions than any theretofore made were offered in an effort to meet the situation. Dispatches from Washington indicated that the railroads supplied to Judge Lovett and to Fuel Administrator Garfield a list of 525 commodities the transportation of which was regarded by the railroads as least essential and it was suggested that an order might shortly be made by Judge Lovett providing that the transportation of such commodities should cease in favor of arms and munitions, coal, food and other absolutely essential commodities.

Coming close on the heels of these dispatches, the railroads east of Chicago agreed to pool all their facilities in an effort to provide greater transportation efficiency. They agreed to pool their shops, coal and other supplies; to pool and redistribute all open top freight cars; to divert traffic from congested railroad lines to open routes, and to ask for a rearrangement of the transportation of coal from mine to market. These matters all seem to be covered in the agreement made by the railroads on April 11, 1917, but were not undertaken by the railroads until the latter part of November and then only in eastern territory. By reason of the anti-pooling section of the Interstate Commerce Act, the agreement of the railroads could not and did not contemplate the pooling of earnings. 
After eight months of effort, the car situation was worse in the latter part of December than it was when the United States entered the war and it was clear that measures more drastic than any theretofore taken would have to be applied if the nation's essential transportation needs were to be supplied.

\section{Railroad Finances}

Railroad finances presented another important and serious war problem.

Prior to the entry of our country into the war, prominent railroad executives made the statement that the railroads needed one billion dollars yearly for at least ten years for the construction of additions, betterments and extensions and to enable the railroads to keep up with the country's requirements for increased terminal facilities, freight and passenger equipment, double tracks and other railroad facilities. I shall not take time now to consider why these necessary improvements were not made by the railroads and why it has been difficult or impossible for many of them to secure the necessary funds. Suffice it to say that the requirements for additional construction and facilities which existed prior to the war were strongly accentuated by the war. During the war, more than ever, the railroads need additional cars, additional locomotives and additional terminal facilities. How could they secure the necessary funds?

The normal method of securing funds for capital expenditures is the sale of securities. During the war, however, it will be practically impossible for the railroads to secure large amounts of additional capital by the issue of their securities on their own credit and their sale to the investing public in competition with liberty bonds and other government securities.

As the war progressed, it became increasingly evident that the railroads would be unable on their own responsibility to meet the war's imperative requirements for additional terminal facilities, double tracks, cars and locomotives.

\section{Labor and Equipment}

One of the most serious problems with which the railroads were confronted as a result of the war was the necessity of securing enough labor to maintain their way, structures and equipment in 
safe and serviceable condition. The call to the armed forces of the nation and the competition of other industries have seriously depleted the supply of labor available to the railroads and they have no effective means to replenish the supply. Likewise, it became increasingly difficult for the railroads to secure the necessary equipment, materials and supplies. Locomotives and cars ordered by the railroads last summer have not been delivered and there seemed no reasonable prospect for their delivery before the expiration of many more months.

\section{Solution of Problem}

As the fall of 1917 advanced, it became more evident, day by day, that the nation's railroad war problem could not be satisfactorily solved under the existing system and that a radical change was imperatively required to prevent a complete break-down of the nation's transportation system.

\section{Report of Interstate Commerce Commission}

In view of these conditions, the Interstate Commerce Commission on December 1, 1917, filed with the Senate and the House of Representatives a special report on transportation conditions as affecting and as affected by the war.

The Commission said in part:

Since the outbreak of the war in Europe, and especially since this country was drawn into the war, it has become increasingly clear that unification in the operation of our railroads during the period of conflict is indispensable to their fullest utilization for the national defense and welfare. They must be drawn, like the individual, from the pursuits of peace and mobilized to win the war. This unification can be effected in one of two ways, and we see but two.

The Commission then stated these two ways. The first is operation as a unit by the carriers themselves, requiring the suspension during the war of the anti-pooling section of the Interstate Commerce Act, a modification of the anti-trust laws in so far as railroads are concerned and loans to the railroads by the government for capital purposes. The second alternative is operation as a unit by the President as a war measure.

Commissioner McChord filed a separate report in which he holds that "the strong arm of governmental authority is essential if the transportation situation is to be radically improved."

That continued private operation of the railroads by the car- 
riers themselves, being the first alternative suggested by the Interstate Commerce Commission, would not solve the problem seems clear for a number of reasons.

First, private operation of the railroads is in its very nature incompatible with war needs. Under private operation, each railroad very naturally seeks to gain all possible traffic so that it may be able to pay interest on its bonds and notes and, if possible, dividends on its stock. The price of failure to secure sufficient traffic is bankruptcy. On the other hand, while the nation is at war, traffic should be moved with an eye solely to the greatest efficiency in helping to win the war. The most efficient operation of the railroads as a war agency may require that traffic be diverted entirely from one railroad whose terminals are blocked to another whose terminals are open; that traffic be diverted in whole or in part from one railroad to another railroad which can be more economically or efficiently operated; that one of two parallel, competing lines be operated solely for west-bound or north-bound freight and the other for east-bound or south-bound freight, or vice versa; that certain railroads stop carrying passengers and that others stop carrying freight; and that any number of other acts be done all of which will take traffic away from one railroad and give it to another and thus interfere with railroad earnings. Private operation in its very nature can not solve these problems. Government operation can.

Second, private operation can not during the war secure the funds imperatively needed by the railroads for additional capital expenditures.

Third, private operation can not during the war secure an amount of labor sufficient to maintain railroad properties in safe and serviceable condition, nor can private operation secure with sufficient promptness all the necessary equipment, materials and supplies.

Hence it appeared quite clearly that the nation would be driven to the alternative of direct operation by the government itself.

\section{President Wilson's Proclamation}

By his proclamation of December 26, 1917, President Wilson took possession and control of all railroads and shipping owned or controlled by them, engaged in general transportation, whether 
operated by steam or electricity. Street railways and electric railroads commonly known as interurbans are for the present excluded from government operation.

The President appointed William G. McAdoo, Secretary of the Treasury, as Director General of Railroads with power to operate all the transportation systems affected by the proclamation. The proclamation declares that until and except so far as the Director may from time to time otherwise determine, the operation of the railroads shall be continued by their officers and employes in the usual and ordinary course of business in the names of their respective companies. The President also directs that until and except so far as the Director may from time to time otherwise determine, the transportation systems affected by the proclamation shall remain subject to all existing statutes and orders of the Interstate Commerce Commission and to all statutes and orders of regulating commissions of the various states. All orders of the Director, however, shall have paramount authority and be obeyed as such. The Director is instructed to enter into arrangements with the various companies for a just and reasonable compensation to be paid to them for the possession and use of their properties "on the basis of an annual guaranteed compensation, above accruing depreciation and the maintenance of their properties, equivalent, as nearly as may be, to the average of the net operating income thereof for the three year period ending June $30,1917 . "$

The result of such negotiations must be reported to the President for his action. The proclamation contains other provisions to which it is not now necessary to refer.

In a statement accompanying the proclamation, President Wilson declared that immediately on the re-assembling of Congress he would recommend that definite guarantees be given to the railroads, first, that their properties will be maintained during the period of federal control in as good repair and as complete equipment as when taken over by the government and, second, that they shall receive a net operating income equal in each case to the average net income of the three years preceding June 30, 1917.

To complete the plan, legislation would also seem to be necessary with reference to the part which the government must undoubtedly play in connection with securing the funds needed for railroad additions, betterments and extensions while under government operation. 
In accordance with the terms of President Wilson's proclamation, the possession of all the transportation systems therein described passed to the government of the United States at noon on December 28,1917 , and they are now being operated under the control of the federal government acting through Director McAdoo.

\section{Results From Government Operation}

It is too early to predict and it may be indelicate to suggest the details of the plan of government operation which must be worked out by Director McAdoo. The broad outlines, however, of what may be accomplished by government operation of the railroads during the war seem well marked. The government can (1) disregard absolutely all previous traffic conditions and can operate the railroads as a single system with an eye solely to the maximum efficiency to meet the nation's war needs; (2) divert all or a part of the traffic, passenger or freight or both, of one railroad and give it to another, which can transport it more economically or efficiently; (3) eliminate all property and employes used and all expenditures incurred in the purely competitive activities of the various railroads, effect tremendous savings in construction and operating expenses, and utilize the man power thus saved for necessary railroad work or for other useful and necessary activities; (4) secure on reasonable terms the funds necessary for additional terminal facilities, equipment and other additions and betterments; (5) secure the labor necessary to keep railway properties in safe and serviceable operating condition and can expedite the manufacture for the railroads of necessary cars, locomotives and other equipment.

That Director McAdoo will be successful in accomplishing these results and will thereby greatly increase this nation's efficiency during the war is the earnest hope of every patriotic citizen.

What the effect of government operation of the railroads will be on the movement for government ownership is a question which will be much discussed. If government operation is a success, a powerful stimulus will undoubtedly be given to government ownership. In the meantime, every effort of the nation should be concentrated on making government operation an unqualified success. Whether government ownership will follow government operation is a question which we can answer when we have won the war. 